\title{
INDIVIDUAL CHARACTERISTICS AS CORRELATES OF ICT ADOPTION IN MAKERERE UNIVERSITY
}

\author{
Fred E Bakkabulindi, Ph.D - EAIHESD Makerere University, Kampala \\ James L. Nkata, PhD - Uganda Management Institute, Kampala \\ Martin E Amin, PhD - University of Yaounde, Cameroon.
}

\begin{abstract}
This Paper reports on part of a survey of ICT adoption in Makerere University carried out early 2005. The survey which involved teaching staff, senior administrators and 144 postgraduate students, sought to investigate links between ICT adoption with individual characteristics (interaction with ICT change agents, ICT training, cosmopolitanism, age, gender and income status). Results indicated low levels of ICT adoption, and the individual characteristics significantly affecting ICT adoption were; interaction with ICT change agents; possession of ICT qualifications; cosmopolitanism before joining university, and; income level of the respondent. Appropriate recommendations toward putting in place training leading to possession of ICT qualifications, and special ICT help (including ICT training) for the less cosmopolitanism, and raising income levels of Makerereans were accordingly suggested.
\end{abstract}

\section{Introduction}

Low levels of ICT adoption in Makerere University have received increasing attention of recent (Agaba, 2003, Niwe, 2000; Nyakoojo, 2002;). This Paper reports on part of a survey on ICT adoption in Makerere University carried out early 2005 with the purpose of linking ICT adoption with individual (lecturer, administrator and student) characteristics, as suggested by Kibera (1997). On the conceptual side, the study considered ICT as an innovation and from the literature, built a conceptual framework that explained ICT adoption as depending on interaction with ICT change agents, ICT training, cosmopolitanism, age, gender, and income status.

Interaction with a relevant change agent (or champion) has been theorized as useful in adoption of innovations (Kibera, 1997) such as agricultural innovations (CIMMYT, 1993 in Basisa, 1999). Training enables employees to be more adaptable, and as technological advances continue to proliferate, it is training that enables employees to cope with the changes (Wamala, 1996). In particular, ICT training raises individual trainees' ICT literacy, contributing to the process of adopting new technology by; (i) providing the means for ICT print media exposure; (ii) allowing the receiver to control the rate of ICT message input; (iii) facilitating the retrieval of ICT print messages for future use, and; (iv) unlocking more complex mental abilities (Kibera,1997). Cosmopolitanism (i.e. urban influence or elitism) has been theorized to be positively related to adoption of innovations such as those in education and agriculture (Rogers \& Shoemaker, 1971) and health (Bonabaana, 2000; Turyaheebwa, 2000) because urban residents have more education (Kintu, 2000), better access to the facilities (Masentle, 1997) and have better access to media (e.g. Internet) peddling innovations (Gakibayo, 2001). 
Kibera (1997) asserts that there are several demographic variables which are hypothesized to influence innovative behaviour, including age, gender and income status: age is theorized to be important in adoption of innovations such as those in agriculture (Basisa, 1999); health and/ or demographic innovations such as family planning (Bonabana, 2000), contraception (Karugaba, nd) and health service utilization (Mayanja, 2001). Gender is hypothesized to be important in innovation adoption process in that the more numerous roles a woman has to play (than a man) like caring for the children, cooking, fetching firewood and water in addition to cultivating land may hinder her from easily adopting a new technology (Ssekiboobo, 1995 in Watuulo, 2000). Income status is believed to be positively related to adoption of ICT (Morales-Gomez \& Melesse, 1998; Obbo, 2001); health and/ or demographic innovations (Mayanja, 2001); agricultural innovations (Galiwango, 2000); and so on.

\section{Hypotheses}

From the above literature, the study was guided by the following hypotheses;

(i) Interaction with ICT change agents is positively correlated with ICT adoption in Makerere University

(ii) ICT training is positively correlated with ICT adoption in Makerere University

(iii) Cosmoplitanism is positively correlated with ICT adoption in Makerere University

(iv) Age is negatively correlated with ICT adoption in Makerere University

(v) Gender is correlated with ICT adoption in Makerere University with the women being at a disadvantage

(vi) Income status is positively correlated with ICT adoption in Makerere University

\section{Method}

Using a quantitative correlational survey design, data were collected from a sample of 145 teachers, 124 senior administrators and 175 postgraduate students using a self-administered questionnaire with 27 questions on knowledge of ICT and 27 questions on actual use of ICT. The questionnaire also had a section on the independent variables under study, namely the following individual characteristics: interaction with ICT change agents or champions (one question); ICT training (one question); cosmopolitanism (five questions); age (one question); income status (one question). The data were analysed using summary statistics (e.g. means, standard deviations), t-test, Analysis of Variance (ANOVA), Correlation Analysis, Factor Analysis and Multiple Regression Analysis.

\section{Findings}

The dependent variable in this study was ICT adoption, conceptualized as knowledge of, and actual use of ICT (Rogers \& Shoemaker, 1971) among staff and students of Makerere University. Thus a section of the instrument was devoted to this dependent variable, with 27 items or questions on knowledge and 27 items or questions on actual use of basic ICT facilities. In each case the respondent was asked to do self-rating in terms of knowledge and/ or use of a particular ICT facility using a scale ranging from a minimum of one for little or no knowledge or use, to a maximum of five for very much knowledge or use. For purposes of correlating ICT adoption with the independent variables, the researcher aggregated all the 27 items or questions on ICT knowledge and the 27 items or questions on ICT use into one index, hereafter referred to as the aggregate 
ICT adoption index, with an arithmetic mean of 2.8 and standard deviation of 0.85 . These results suggest that ICT adoption in Makerere University is low, given that the arithmetic mean is below the median (3 i.e. neither low nor high adoption). However the distribution of the index was normally distributed, which implied that the index could be confidently subjected to linear regression analyses (Sweet \& Grace-Martin, 2003). Now the aggregate ICT adoption index is related to the respective independent variables in the study:

\section{Interaction with ICT change agents and ICT adoption}

The study sought to assess the effect interaction with ICT change agents or champions had on ICT adoption in Makerere University, taking this interaction as the existence of an ICT change agent or champion in the unit (i.e. school, faculty, institute or adminis146 trative dept.) the respondent was in, and Table 1 gives ANOVA results on the aggregate ICT adoption index by presence of ICT change agent:

Table 1: ANOVA results on ICT adoption by presence of ICT change agent

\begin{tabular}{|l|c|l|l|l|}
\hline $\begin{array}{l}\text { Had unit ICT change } \\
\text { agent? }\end{array}$ & $\begin{array}{l}\text { Frequency } \\
\text { (\%) }\end{array}$ & $\begin{array}{l}\text { Arithmetic } \\
\text { mean }\end{array}$ & $\begin{array}{l}\text { Standard } \\
\text { deviation }\end{array}$ & ANOVA \\
\hline No & $99(24.6)$ & 2.70 & 0.78 & $\begin{array}{l}\mathrm{F}=8.39 ; \mathrm{p}= \\
0.000 \\
\text { Yes }>\text { Not obser- } \\
\text { vant }\end{array}$ \\
\cline { 1 - 3 } Yes & $218(54.1)$ & 2.92 & 0.87 & \\
\hline Not observant & $86(21.3)$ & 2.51 & 0.75 & $\mathbf{0 . 8 4}$ \\
\cline { 1 - 3 } Total & $\mathbf{4 0 3 ( \mathbf { 1 0 0 . 0 ) }}$ & $\mathbf{2 . 7 8}$ & \multicolumn{2}{|l}{} \\
\hline
\end{tabular}

ANOVA results (Table 1) indicated significant differences in ICT adoption ( $\mathrm{F}=8.39$; $\mathrm{p}=0.000$ ) with those who claimed to have ICT change agents in their units scoring a significantly higher (mean $=2.92$ ) than those who claimed not to have been observant as to whether their units had ICT change agents or not (mean $=2.51)$, thus suggesting the importance of ICT change agents in fostering ICT adoption in Makerere University, at the one percent level of significance $(p<0.01)$.

\section{ICT training and ICT adoption}

The study aimed at assessing the effect of ICT training on ICT adoption in Makerere University, conceptualizing ICT training as possession of an ICT qualification, and Table 2 gives t-test results on the aggregate ICT adoption index by possession of ICT qualification;

Table 2: T-test results on ICT adoption by possession of ICT qualification

\begin{tabular}{|c|c|c|c|c|}
\hline $\begin{array}{l}\text { Had ICT qualifica- } \\
\text { tion? }\end{array}$ & Frequency (\%) & $\begin{array}{l}\text { Arithmetic } \\
\text { mean }\end{array}$ & $\begin{array}{l}\text { Standard } \\
\text { deviation }\end{array}$ & $T$ test \\
\hline No & 212 (51.0) & 2.54 & 0.81 & \multirow{3}{*}{$\begin{array}{l}t=6.32 ; F= \\
39.93 ; \\
p=0.000 ; \text { Yes } \\
>\text { No }\end{array}$} \\
\hline Yes & $204 \quad(49.0)$ & 3.05 & 0.81 & \\
\hline Total & $416(100.0)$ & 2.79 & 0.85 & \\
\hline
\end{tabular}


Table 2 reveals significant differences in mean ICT adoption $(\mathrm{t}=6.32$ or $\mathrm{F}=39.93 ; \mathrm{p}=$ 0.000 ) with those who claimed to have ICT qualifications scoring higher levels (mean $=3.05)$ than those who claimed not to have them (mean $=2.54)$, thus suggesting the importance of ICT qualifications in fostering ICT adoption in Makerere University, at the one percent level of significance $(\mathrm{p}<0.01)$.

\section{Cosmopolitanism and ICT adoption}

The study sought to assess the effect of cosmopolitanism on ICT adoption in Makerere University, taking this cosmopolitanism as ranging from the worst case scenario of "rural poor" to the best case scenario of "urban elite". Thus respondents were asked to do self-rating as to the places where they had their childhood before school; where they had primary schooling; where they had O-level and A-level secondary schooling and where they are now, using a scale ranging from a minimum of one for rural poor, through two for rural but elite, three for urban poor, to a maximum of four for urban elite, and the responses in descending order of means, are in Table 3:

Table 3 Descriptive statistics on cosmopolitanism at different levels in life

\begin{tabular}{|l|l|l|l|}
\hline $\begin{array}{l}\text { Cosmopolitanism at a given } \\
\text { level in life }\end{array}$ & $\begin{array}{l}\text { Number of } \\
\text { respondents }\end{array}$ & $\begin{array}{l}\text { Arithmetic } \\
\text { mean }\end{array}$ & $\begin{array}{l}\text { Standard devia- } \\
\text { tion }\end{array}$ \\
\hline Current place of abode & 437 & 3.61 & 0.70 \\
\hline A-level schooling place & 431 & 3.09 & 0.96 \\
\hline O-level schooling place & 428 & 2.81 & 1.02 \\
\hline Primary schooling place & 434 & 2.27 & 1.09 \\
\hline Childhood place & 423 & 2.17 & 1.13 \\
\hline
\end{tabular}

Table 3 reveals that on average, respondents claimed to have had non-cosmopolitan environments during childhood (mean $=2.17$ ), rising minimally when they joined primary school (mean $=2.27$ ) but still non-cosmopolitan; and crossed to cosmopolitan environments starting at O-level $($ mean $=2.81)$ through A-level $($ mean $=3.09)$ to current place of abode (mean $=3.61$ ). The five indicators of cosmopolitanism were reduced to only one factor (using Factor Analysis), accounting for almost 58\% of the variation among the variables, and the component matrix (Kaiser, 1958's Varimax Rotation as recommended by Foster, 1998 and Manly, 1994 was not possible because of one component) in Table 4:

Table 4 (Unrotated) component matrix for factors on cosmopolitanism

\begin{tabular}{|l|l|}
\hline Cosmopolitanism at a given level in life & Component \\
\hline Childhood place & 0.825 \\
\hline Primary schooling place & 0.871 \\
\hline O-level schooling place & 0.858 \\
\hline
\end{tabular}




\begin{tabular}{|l|l|}
\hline A-level schooling place & 0.776 \\
\hline Current place of abode & \\
\hline
\end{tabular}

Taking only high factor loadings in Table 4 (i.e. above 0.5 as per Foster, 1998; Manly, 1994), the resulting one and only one component seemed to be; "cosmopolitanism before university", which when correlated with the aggregate ICT adoption index, gave $r=0.263(p=0.000)$, which suggested a significant positive relationship between cosmopolitanism (before university) and ICT adoption in Makerere University, at the one percent level of significance $(\mathrm{p}<0.01)$.

\section{Age and ICT adoption}

Another objective of the study was to assess the effect of age on ICT adoption in Makerere University. Thus respondents were asked to state their ages to the nearest whole year from which the following summary statistics were got: number of respondents, $\mathrm{n}=$ 413; range $=47$; minimum $=22$; maximum $=69$; arithmetic mean $=36$ and standard deviation $=9.25$. Thus on average, respondents were slightly above youthful age (mean $>$ 35) mainly because target respondents included only teaching staff, administrators and postgraduate students. Correlation between age and the aggregate ICT adoption index, gave $r=-0.144(p=0.003)$, suggesting a significantly negative relationship, implying that the older the respondent in Makerere University, the less the expected level of ICT adoption at the one percent $(\mathrm{p}<0.01)$.

\section{Gender and ICT adoption}

The study also wanted to establish the effect of gender on ICT adoption in Makerere University. Thus respondents were asked to state their genders from which Table 5 gives t-test results on the aggregate ICT adoption index by gender:

Table 5 T-test results on ICT adoption by gender

\begin{tabular}{|l|l|l|l|l|}
\hline Gender & Frequency (\%) & $\begin{array}{l}\text { Arithmetic } \\
\text { mean }\end{array}$ & Standard deviation & T test \\
\hline Female & $147(33.9)$ & 2.82 & 0.80 & \multirow{2}{*}{$\begin{array}{l}0.09 \\
0.093 \\
\mathrm{p}=0.770\end{array}$} \\
\hline Male & $286(66.1)$ & 2.80 & 0.87 & 0.85 \\
\hline Total & $433(100.0)$ & 2.81 & $\mathrm{~F}=$ \\
\hline
\end{tabular}

Table 5 reveals that both genders scored same mean on the aggregate ICT adoption index $(t=0.293$ or $F=0.09 ; p=0.770)$, indicating that gender may not be a significant correlate of ICT adoption in Makerere University, at the five percent level of significance $(\mathrm{p}>0.05)$.

\section{Income level and ICT adoption}

Pursuant to the study objective of finding out how income level relates to ICT adoption in Makerere University, respondents were prompted to state their perceived income levels using a scale ranging from a minimum of one for low, through two for medium or middle, to a maximum of three for high, and Table 6 gives ANOVA results on the aggregate ICT adoption index by income level: 
Table 6 ANOVA results on ICT adoption by income level

\begin{tabular}{|c|c|c|c|c|}
\hline Income level & Frequency (\%) & $\begin{array}{l}\text { Arithmetic } \\
\text { mean }\end{array}$ & $\begin{array}{l}\text { Standard de- } \\
\text { viation }\end{array}$ & ANOVA \\
\hline Low & $131(30.9)$ & 2.65 & 0.83 & \multirow{4}{*}{$\begin{array}{l}F=3.12 \\
p=0.045\end{array}$} \\
\hline Medium/middle & 271 (63.9) & 2.86 & 0.85 & \\
\hline High & $22 \quad(5.2)$ & 2.96 & 0.85 & \\
\hline Total & $424(100.0)$ & 2.80 & 0.85 & \\
\hline
\end{tabular}

Table 6 reveals that the aggregate ICT adoption index tended to rise with income level $(\mathrm{F}=3.12 ; \mathrm{p}=0.045)$, suggesting that income level may be a significant correlate of ICT adoption in Makerere University, at the five percent level $(\mathrm{p}<0.05)$.

\section{Testing for individual characteristics that had significant influence on ICT adoption in the University}

Bivariate analyses suggested that all but one (gender) of the above individual characteristics were potential correlates of ICT adoption in Makerere University. However to establish the real correlates, use was made of a more powerful multivariate tool, Multiple Regression Analysis, which took into account simultaneous relationships of the many variables thus documenting collective effects and accounting for potentially spurious factors (Sweet \& Grace-Martin, 2003). But before fitting the multiple regression model, independent variables were treated as follows: Because of its categorical nature, a dummy was created from Table 1 for the existence of an ICT change agent in the respondent's unit as follows ( $0=$ none or not observant whether there is; $1=$ yes $)$; another dummy was also created from Table 2 for respondent's possession an ICT qualification as follows $(0=$ none; 1 = yes). The factor "cosmopolitanism before university" (Table 4 ), being a continuous variable, was used in the model as it was without modification. Being a continuous variable, age was used in the model as given by the respondents with no modification. Being a categorical variable, a dummy was created from Table 5 for the respondent's gender as follows $(0=$ female; $1=$ male). Income level (Table 6$)$ was taken as a continuous variable, and used in the model as given by respondents with no modification. Hence a multiple regression analysis of the aggregate ICT adoption index on all the individual characteristics, yielded the results in Table 7:

Table 7 Regression results of ICT adoption on individual characteristics

(a)

ANOVA table

\begin{tabular}{|l|l|l|}
\hline F statistic & Significance level & Adjusted R square \\
\hline 11.68 & .000 & 0.165 \\
\hline
\end{tabular}

(b)

Coefficients

\begin{tabular}{|l|l|l|}
\hline & Beta & Significance level, $\mathbf{p}$ \\
\hline
\end{tabular}




\begin{tabular}{|l|l|l|}
\hline Constant & & 0.000 \\
\hline ICT change agent dummy & 0.11 & 0.034 \\
\hline ICT qualification dummy & 0.25 & 0.000 \\
\hline Cosmopolitanism before university & 0.21 & 0.000 \\
\hline Age of respondent (yrs) & -0.10 & 0.084 \\
\hline Gender dummy & 0.06 & 0.261 \\
\hline Income level of respondent & 0.13 & 0.018 \\
\hline
\end{tabular}

Part (a) of Table 7 suggests that the individual characteristics considered, were collectively good explanatory variable of ICT adoption in Makerere University $(\mathrm{F}=11.68 ; \mathrm{p}$ $=0.000$ ), although accounting for only about $17 \%$ of the variation in the aggregate ICT adoption index (Adjusted R square $=0.165$ ). Table 7 (Part b) further suggests that the four most significant correlates of ICT adoption in order of priority were; possession of an ICT qualification (ICT qualification dummy: Beta, $\square=0.25 ; \mathrm{p}=0.000$ ) at the one percent level of significance $(\mathrm{p}<0.01)$; followed by cosmopolitanism before joining university (Beta, $\square=0.21 ; \mathrm{p}=0.000$ ) also at the one percent level of significance ( $\mathrm{p}<$ 0.01 ); income level of respondent (Beta, $\square=0.13 ; \mathrm{p}=0.018$ ) at the five percent level of significance $(p<0.05)$; and trailed by interaction with ICT change agent (ICT change agent dummy: Beta, $\square=0.11 ; \mathrm{p}=0.034)$ at the five percent level of significance $(\mathrm{p}<$ $0.05)$.

\section{Discussion, Conclusions and Recommendations}

The study has suggested that ICT adoption in Makerere University is low, corroborating earlier researchers who found this to be true in the areas of utilization of computers in the management of students' information such as admissions (Nakaye, 1998; Zziwa, 2001); Internet utilisation by teaching staff as source of information (Agaba, 2003; Niwe, 2000); student participation in ICT usage and management (Nassanga, 2001), and teaching (Nyakoojo, 2002). Now the discussion, conclusions and recommendations turn to the influence of each individual characteristic on ICT adoption:

\section{Interaction with ICT change agents and ICT adoption}

The first hypothesis of the study namely that interaction with ICT change agents or champions is significantly positively correlated with ICT adoption in Makerere University, was supported by the findings, corroborating earlier researchers (e.g. Luwedde, 1997) but inconsistent with others (e.g. Ezati, 1998; Kironde, 1998;). The finding leads to one major conclusion and recommendation, namely that one way to foster ICT adoption in Makerere University, is for the respective units (i.e. schools, faculties, institutes and administrative departments) to put in place observable ICT change agents.

\section{ICT training and ICT adoption}

The study set out to test the relevance of ICT training in enhancing ICT adoption in Makerere University, which hypothesis was supported by the findings, in congruence with Mwanja (2001), Wakanyasi (2002) and Fedorowicz \& Gelinas (1998). This could be because as Kibera (1997) argues, adaptability to technological advances is a factor of training. Thus the study had enough ground to conclude and hence recommend that 
if ICT adoption is to take root in Makerere University, appropriate ICT training should be put in place.

\section{Cosmopolitanism and ICT adoption}

As hypothesized in the study, findings have upheld the importance of cosmopolitanism in enhancing ICT adoption in Makerere, in agreement with Nafuna (2002), but at variance with some other studies (Van de Ban \& Hawkins, 1996) which did not. The explanation for the findings could be because innovations start from urban or cosmopolitism areas (Bisaso \& Visscher, 2005) and spread to other areas. The study thus concludes that a cosmopolitan background enhances ICT adoption. The researcher thus recommends that those from the less cosmopolitan backgrounds be given special ICT assistance such as preference when training and/ or giving them encouragement to enhance their exposure to ICT informally via reading ICT magazines, and the like.

\section{Age and ICT adoption}

While the study findings agreed with the initial hypothesis that age is negatively related to ICT adoption in Makerere University, the findings did not reach a significant level, consistent with Ehikhamenor (1999) but not with others (e.g. Edema, 1997; Galiwango, 2002). The explanation for the finding could be that while young Makerereans tend to have more exposure to ICT at earlier levels, the older ones may have more ICT use experience and resources to acquire ICT facilities, hence the counterbalancing effect (Basisa, 1999). In conclusion, while age may not have proved an important correlate of ICT adoption in Makerere University, the aged and aging could still be encouraged to keep a breast with ICT via informal exposure to ICT via reading ICT magazines, attending ICT seminars and the like (Moyo, 1996).

\section{Gender and ICT adoption}

While the study set out on the premise that ladies were at a disadvantage as far as ICT adoption is concerned, the study findings proved otherwise, a finding similar to that of Ehikhamenor (1999), but disagreeing with others (Mburu, Massimo \& Mutua, 2000). The possible explanation for the study finding is that the levels of ICT adoption are so low in Makerere that they cut across the gender divide: In other words both males and females in Makerere University are equally poor at ICT adoption.

\section{Income level and ICT adoption}

Consistent with the hypothesis in the study, income level positively correlated with ICT adoption in Makerere University, a finding similar to that of several other studies (e.g. Matovu, 2003; Mugweri, 2000; Mwanja, 2001; Nafuna, 2002; Njiraine, 2000; Omona, 2001). The said positive correlation could be because the higher the income, the easier it is for the individual to acquire personal ICT facilities, and to get informal exposure to ICT through ICT magazines and newspapers (Moralez-Gomez \& Melesse, 1999). The study thus concludes that if ICT adoption in Makerere University is to be enhanced, then effort should be made to raise the income levels of at least the staff members, so that they have higher chances of acquiring personal ICT facilities and written materials on ICT or even provide loans for acquisition of ICT facilities like Dar es Salaam University did (Komba, 2002). 


\section{Ackknowledgement}

The authors gratefully acknowledge Carnegie Corporation of New York through the School of Graduate Studies, Makerere University for funding the study.

\section{References}

Agaba, D. (2003). Utilization of Makerere University Library electronic information resources by academic staff : Challenges and the way forward. Unpublished Masters (of Sc in info Sc) dissertation, Makerere University, Kampala, Uganda.

Basisa, M. C. (1999). Farmer characteristics influencing the adoption of organic farming techniques among the partner farmers of Africa 2000 Network in Kasese District Uganda. Unpublished Masters dissertation, Makerere University, Kampala, Uganda.

152 Bisaso, R. \& Visscher, A. (2005). Computerised school information systems in an emerging country - Uganda. In Tatnall, A., Osorio, J. \& Visscher, A. (Eds.). Information technology in education management in the knowledge society. IFIP TC3 WG3. 7, 6th International Working Conference on ITEM, July 11-15, 2004, Las Palmas de Gran Canaria, Spain. NY: Springer.

Bonabaana, C. D. (2000). Use of family planning methods in Mbarara District . Unpublished Bachelor dissertation, Makerere University, Kampala, Uganda.

Edema, L. R. (1997). Adoption constraints of agro forestry technologies in Mpigi District. Unpublished Masters (of Sc. Forestry) dissertation, Makerere University, Kampala, Uganda.

Ehikhamenor, F. A.. (1999). Cognitive information foundation of university students: Index of ICT in Nigeria. Information Technology for Develoment, 8 (3), 134-144.

Ezati, E. (1998). Socio-economic factors of traditional and modern contraceptive in Northern Uganda. Unpublished Masters dissertation, Makerere University, Kampala, Uganda.

Fedorowicz, J. \& Gelinas, U. J. Jr. (1998). Adoption and usage patterns of COBIT: Results from a survey of COBIT purchases. [Information systems] IS Audit \& Control Journal, 6, 45-51. Foster, J. J. (1998). Data analysis using SPSS for Windows. London: Sage.

Gakibayo, A. (2001). Internet use in academic institutions: A case of Mbarara University of Science and Technology (MUST). Unpublished Bachelors (of Librarianship \& Info. Sc.) dissertation, Makerere University, Kampala, Uganda.

Galiwango, S. (2000). Factors affecting transfer and utilization of selected post-harvest technologies in Kamuli District, Uganda. Unpublished Masters (of Sc. Agric Ext./ Educ.) dissertation, Makerere University, Kampala, Uganda. Karugaba, R. (nd). Factors influencing contraceptive use: A case study of Buhunga Parish in Rukungiri District. Unpublished Bachelor (of Arts, Sociology) dissertation, Makerere University, Kampala, Uganda.

Kibera, F. N. (1997). Critical review of theories of adoption of innovations. Makerere Business Journal (pp.195-204): Summary of papers presented at the $4^{\text {th }}$ Annual International Management Conference on the theme: Modernisation of African economies; challenges and strategies, Nov 24- 28, organised by the Makerere University Business School, Kampala. 
Kintu, T. M. (2000). Determinants of contraceptive use in Nakawa Division. Unpublished Bachelors (of Sc. Quant. Econ.) dissertation, Makerere University, Kampala, Uganda.

Kironde, J. (1998). Participation of women in the sericulture industry in Mpigi District. Unpublished Masters dissertation, Makerere University, Kampala, Uganda.

Komba, W. L. M. (2002). Globalisation and the digital divide: Customizing asynchronous networks to enhance higher education delivery in East Africa: Experiences from the University of Dar es Salaam. Paper presented at the Inter-University Council of East Africa Conference on contemporary issues in education: Globalisation and local empowerment, September 16-17, 2002. Organised by the School of Education, Makerere University, Kampala.

Luwedde, I. (1997). Factors influencing adoption of improved post-harvest technologies of tomatoes among small-scale farmers in Mukono District. Unpublished Master (of Agric. Ext./ Educ.) dissertation, Makerere University, Kampala, Uganda.

Manly, B. J. F. (1994). Multivariate statistical methods: A primer ( $2^{\text {nd }}$ ed.). London: Chapman \& Hall.

Masentle, A. M. (1997). Socio-economic determinants of knowledge, attitudes and use of family planning in Lesotho. Unpublished Masters dissertation, Makerere University, Kampala, Uganda.

Matovu, J. (2003). Information technology issues in Uganda's education sector. Uganda Journal of Education, 4, 9-23.

Mayanja, S. P. (2001). Barriers to utilization of mother-to-child package in selected districts in Uganda. Unpublished Masters dissertation, Makerere University, Kampala, Uganda.

Mburu, P. T., Massimo, S. K. \& Mutua, K. (2000). How are Internet facilities being used in Botswana? Makerere Business Journal (pp.81-98): Summary of papers presented at the $7^{\text {th }}$ Annual International Management Conference on the theme: Coping with economic and technological change in the New Millennium, Dec 4-7, 2000, organised by the Makerere University Business School, Kampala.

Moralez-Gomez, D. \& Melesse, M. (1998). Utilising information and communication technologies for development: Social dimensions. Information Technology forDdevelopment, $8(1), 3-13$.

Moyo, L. M. (1996). Information technology strategies for African survival in the Twentyfirst Century: IT all pervasive. Information Technology for Development, 7 (1),17-27.

Mugweri, R. A. (2000). An assessment of the opportunities and challenges of exploiting ICT networks to improve efficiency and effectiveness in government operations: A case study of MFPED. Unpublished Masters (of Sc in info Sc.) dissertation, Makerere University, Kampala, Uganda.

Mwanja, J. (2001). Computerisation in government ministries in Uganda. Unpublished Masters dissertation, Makerere University, Kampala, Uganda. 
Nafuna, S. A. (2002). Impact of Internet service providers (ISPS) on electronic information provision in Uganda: A study of selected ISPs in Kampala. Unpublished Bachelor (of library and information science) dissertation, Makerere University, Kampala, Uganda.

Nakaye, A.. (1998). Information utilization in managing admissions of students at Makerere University. Unpublished Masters (of Public adm. \& mgt) dissertation, Makerere University, Kampala, Uganda.

Nassanga, M. (2001). Students' participation in ICT usage and management: A case study of EASLIS. Unpublished Bachelors (of librarianship and info Sc.) dissertation, Makerere University, Kampala, Uganda.

Niwe, M. (2000). Assessing the potential of using the Internet as a tool for meeting infor154 mation needs of academic staff in Makerere University. Unpublished Masters (of Sc in info Sc) dissertation, Makerere University, Kampala, Uganda.

Njiraine, D. M. (2000). Underutilization of Internet facilities at universities: A case study of Jomo Kenyatta Memorial Library (JKML), University of Nairobi and United States International University of Africa (USIUA) Library. Unpublished Masters (of Sc. in info Sc) dissertation, Makerere University, Kampala, Uganda.

Nyakoojo, S. A. (2003). Training and individual learning at Makerere University Business School. Unpublished Masters (of business adm.) dissertation, Makerere University, Kampala, Uganda.

Obbo , D. F. (2001). Gender and the Internet: An analysis of the portrayal of gender in Uganda websites on the Internet. Unpublished Masters (of Sc. Info. Sc.) dissertation, Makerere University, Kampala, Uganda.

Omona, W. (2001). Impact of information and communication technology (ICT) in accessing and disseminating health information in selected health institutions in Kampala District, Uganda. Unpublished Masters (in info Sc) dissertation, Makerere University, Kampala, Uganda.

Rogers, E. M. (2003). Diffusion of innovations (5 ${ }^{\text {th }}$ ed.). NY: Free Press.

Rogers, E. M. \& Shoemaker, F. (1971). Communication of innovations: A cross-cultural approach. NY: Free Press.

Sseguya, H. (2000). Factors that affect adoption of soil fertility management technologies in the banana-based agriculture of the L. Victoria Basin. Unpublished Masters (of Sc. Agric Ext. /Educ.) dissertation, Makerere University, Kampala, Uganda.

Sweet, S. A. \& Grace-Martin, K. (2003). Data analysis with SPSS: A first course in applied Statistics ( $2^{\text {nd }}$ ed.). Boston: Allyn \& Bacon.

Turyaheebwa, E. G. (2000). Factors influencing KAP of modern contraception among women in Kampala District .Unpublished Masters (of Arts, Demo.) dissertation, Makerere University, Kampala, Uganda. 
Wakanyasi, N. (2002). Capacity utilization of information technology in organisations: A case study of Nkumba University. Unpublished Masters (of business adm.) dissertation, Nkumba University, Entebbe, Uganda.

Wamala, B. F. (1996). Management training and performance: Factors that hinder the transfer of skills. Unpublished Masters (of Bus. Adm.) dissertation, Makerere University, Kampala, Uganda.

Watuulo, J. (2000). Gender and women's utilization of health services in Mabanga Village, Mbale District._Unpublished Masters (of Arts, Sociol.) dissertation, Makerere University, Kampala, Uganda.

Zziwa, G. (2001). Computer utilization in the management of students' information at Makerere. Unpublished Masters (of Arts in educ. mgt.) dissertation, Makerere University, Kampala, Uganda. 